\title{
Administrative Staff Perception of Human Resource Management in Tertiary Institutions in South Eastern Nigeria
}

\author{
Obi, Bibiana Irukaku \\ Department of Technology \& Vocational Education \\ NnamdiAzikiwe University, Awka, Anambra State.
}

\begin{abstract}
This study investigated the extent administrative staff perceived human resources management in tertiary institutions in South Eastern Nigeria. The focus was on the conduct staff training and development, staff appraisal and promotion. Two research questions guided the study. This study was carried out in South Eastern Nigeria. The study was a descriptive survey. All the government owned tertiary institutions in the area were studied. The population of this study comprised 2083 principal officers, unit heads and senior registry staff from colleges of education, polytechnic and universities in South Eastern Nigeria. A sample size of 336 principal officers, unit heads and senior registry staff colleges of education, polytechnic and universities was selected based on a normal confidence level of 0.05 to determine the sample size using Taro Yamane's formula. Proportionate sampling technique was used. A researcher-developed questionnaire was used in data collection. The instrument was duly validated in Nnamdi Azikiwe University, Awka. The reliability of the instrument was obtained a pilot study conducted in South-South, Nigeria. Data got from the pilot study were analyzed using Cronbach alpha. The reliability coefficient was 0.81 Copies of the instrument were administered directly on the respondents by the researcher and with the help of 4 research assistants. Data collected were analyzed using mean ratings to answer the research questions. Findings indicated that that colleges of education in the area, to a very low extent, conduct performance appraisal and promotion objectively based on laid down procedures in the institution. Among others, it recommended that Colleges of education in South Eastern Nigeria should conduct performance appraisal and promotion to a great extent and objectively based on laid down procedures in the institution.
\end{abstract}

Keywords:- Administrative staff, human resources, utilization, tertiary institutions.

\section{INTRODUCTION}

The success and failure of any organization to a large extend depends on the availability and quality of human resources in that organization. Human resources, whether in public or private sector corporate world or in the world of education are the assets on which competitive advantages are built.

Human resource is a term used to describe the individuals who make up the workforce of an organization (Haslinda, 2009). Human resources include all the experiences, skill, judgment, abilities, knowledge, contacts, risk-taking and wisdom of individual and associates in an organization. They are the people working or available for work or service in the organization (Kelly 2001).

Human resources are crucial in achieving school goals. The human resources in the tertiary institutions include the principal officers, the lecturers, non teaching staff and the students that work and render their services to the institution. Without human resources in an academic institution, educational goals and objectives of the institution cannot be achieved. Achieving institutional success is by working and through human beings. In order to maximize educational effectiveness, human potentials, individuals' capabilities, time and talents must be managed. Moreover, the efficiency with which an organization can perform will depend to a large extent, on how its human resources are managed and utilized (Onah 2018).

Human resource management is therefore the strategic integrated and coherent approach to the employment, development and well-being of the people in organization (Armstrong, 2009). It comprises of a set of policies designed to maximize organizational integration, employee commitment, flexibility and quality of work (Guest, 1990). It is a distinctive approach to employment management which seeks to achieve competitive advantage through the strategic deployment of highly committed and capable workforce, using an integrated array of cultural, structural and personal techniques (Story, 1995). Boxall, purcel . and wright (2007), defined human resource management as the management of works and people towards ends. For Grimshaw and Robbery (2007), human resource management is concerned with how organization manages their workforce. Human resource management 
encompasses those activities designed to provide for and co-ordinate the human resource of an organization (Byars and Rue 2004). Armstrong (2009) agreed that human resource management involves employment of people, effective management of people and management of works in tunes with the organizational culture for optimal achievement of organizational objectives.

Human resource management form one of the cardinal leadership. The responsibility of the administrator in achieving the goals of the institution in particular and in education in general can never be over emphasized. Human resource in tertiary institution includes teaching and nonteaching staff - clerks, watchmen, labourers, laboratory attendants, students etc. In academic institutions, lecturers are the most potent weapons in the hands of the administrators in achieving the institutional objectives. They should be handled adroitly for they possess the capability to mar the institution and its programmes ( $\mathrm{Ndu}$, Ocha and Okeke, 1997).

In every institution, human resource management is crucial. It is not just the idea of engaging the commitment of staff with the goals of the organization, nor just about administering the staff but also about shaping the staff, increasing their talent to achieve the goals of the institution and as well, making staff participate in decision making in matters that concern them so that they become satisfied in their job and in fulfilling their goals. In human resource management there is need for emphasis on satisfaction of human needs and welfare as well as production effectiveness and efficiency for achievement of educational goals (Ndu 2002).

Human resource management practices are carried out by all those in leadership roles in an organization. Every manager or team leader is necessarily involved and concerned about the way in which people are employed as well as what they need to be doing and how well (Cole, 2002). The key element of human resource management includes job analysis, recruitment and selection, training and staff development, induction and orientation, performance, rewards and compensation, delegation and assignment of teachers to duties , supervision, transfer, promotion, health, safety and employee well being, retirement etc. In educational institution in Nigeria, the people responsible for human resource management are the administrative staff.

Administrative staff in the tertiary institutions are the people in the institutions that provide administrative and instructional leadership and manage the day-to-day activities in the institution. According to Lucky (2011) they are the people in administrative position in tertiary institutions, who set educational standards and goals and establish policies and procedures required to achieve them. They are the people who supervise managers, support staff, lecturers, counsellors, librarians and other employees in order to achieve the university goals and objectives.
In the views of Sanbo (2011) administrative staff include those who develop academic programmes, monitor students' academic progress, train and motivate teachers (lecturers) and other staff, manage career counseling and other student services, administer recordkeeping, prepare budgets, and perform many other duties in the institution. Thus, they are the people that set the school goals and monitor the execution of actions towards the achievement of the set goals. According to Ajayi and Omirin (2007), they are the directors or supervisors, who oversee the institutions daily activities and operations, hire and develop staff, and ensure that the institution meets required regulations and educational standards. This study investigated the extent administrative staff perceived human resources management in tertiary institutions in South Eastern Nigeria. The focus was on extent universities, polytechnics and colleges of education conduct staff training and development, staff appraisal and promotion objectively and based on laid down procedures in the institutions.

\section{Research Questions}

Two research questions guided the study.

- To what extent do administrative staff perceive staff training and development as done objectively based on laid down procedures in the institution?

- To what extent do administrative staff perceive performance appraisal and promotion as done objectively based on laid down procedures in the institution?

\section{RESEARCH METHOD}

This study was carried out in South Eastern Nigeria. The study was a descriptive survey. All the government owned tertiary institutions in the area were studied. The population of this study comprised 2083 principal officers, unit heads and senior registry staff from colleges of education, polytechnic and universities in South Eastern Nigeria. A sample size of 336 principal officers, unit heads and senior registry staff colleges of education, polytechnic and universities was selected based on a normal confidence level of 0.05 to determine the sample size using Taro Yamane's formula. Proportionate sampling technique was used whereby a percentage of the sample drawn from each institution was calculated and the proportion of 16 percentages was calculated from the sample size. A researcher-developed questionnaire was used in data collection. The instrument was validated in Nnamdi Azikiwe Universitty, Awka using 3 experts: two in Educational Management and Policy Department and one in Department of Educational Foundations. The reliability of the instrument was obtained a pilot study conducted in South-South, Nigeria. Data got from the pilot study were analyzed using Cronbach alpha. The reliability coefficient was 0.81 and was considered high enough for the study. Copies of the instrument were administered directly on the respondents by the researcher and with the help of 4 research assistants. Data collected were analyzed using mean ratings to answer the research questions. 


\section{RESULTS}

Research Question 1: To what extent do administrative staff perceive staff training and development as done objectively based on laid down procedures in the institution?

\begin{tabular}{|c|c|c|c|c|c|c|c|}
\hline \multirow[t]{2}{*}{$\mathbf{S} / \mathbf{N}$} & \multicolumn{7}{|l|}{ TRAINING AND DEVELOPMENT } \\
\hline & $\begin{array}{l}\text { To what extent are the following practiced in your } \\
\text { institution? }\end{array}$ & $\begin{array}{l}\text { Uni. } \\
(\mathrm{x})\end{array}$ & Rmk & $\begin{array}{c}\text { Poly } \\
(\mathrm{x})\end{array}$ & Rmk & $\begin{array}{l}\mathrm{COE} \\
(\mathrm{x})\end{array}$ & Rmk \\
\hline 1. & $\begin{array}{l}\text { Inviting resource persons to the school to help staff } \\
\text { up-date their knowledge on current trends }\end{array}$ & 2.58 & GE & 2.84 & GE & 2.50 & LE \\
\hline 2 & $\begin{array}{c}\text { Encouraging staff to attend refresher courses and part } \\
\text { time programmes. }\end{array}$ & 2.60 & GE & 2.71 & GE & 2.81 & GE \\
\hline 3. & $\begin{array}{l}\text { Motivating staff to attend conferences in their areas of } \\
\text { specialization. }\end{array}$ & 2.79 & GE & 2.68 & GE & 2.86 & GE \\
\hline 4. & $\begin{array}{l}\text { Recommending staff that are given special function } \\
\text { for training on that function example, sports and } \\
\text { games. }\end{array}$ & 2.52 & GE & 2.81 & GE & 2.81 & GE \\
\hline 5. & $\begin{array}{l}\text { Encouraging the board in-charge to equip institution's } \\
\text { library with current books and news papers to help } \\
\text { staff up-date their knowledge. }\end{array}$ & 2.42 & ME & 2.34 & ME & 2.68 & GE \\
\hline 6. & $\begin{array}{l}\text { Increasing staff confidence and commitment through } \\
\text { organizing seminars in the school in which the staff } \\
\text { share new ideas. }\end{array}$ & 2.24 & $\mathrm{ME}$ & 2.32 & ME & 2.04 & ME \\
\hline & Grand Mean & 2.53 & GE & 2.62 & GE & 2.61 & GE \\
\hline
\end{tabular}

Table 1:- Mean Ratings on Staff Training and Development

Results in Table 1 indicated that universities, polytechnics and colleges of education in South Eastern Nigeria train and develop their staff to great and objectively based on laid down procedures in the institution.

Research Question 2: To what extent do administrative staff perceive performance appraisal and promotion as done objectively based on laid down procedures in the institution?

\begin{tabular}{|c|c|c|c|c|c|c|c|}
\hline $\mathbf{S} / \mathbf{N}$ & PERFORMANCE APPRAISAL AND PROMOTION & & & & & & \\
\hline & $\begin{array}{l}\text { To what extent are the following practiced in your } \\
\text { institution? }\end{array}$ & $\begin{array}{c}\text { Uni. } \\
(\mathrm{x})\end{array}$ & Rmk & $\begin{array}{c}\text { Poly } \\
(\mathrm{x})\end{array}$ & Rmk & $\operatorname{COE}(\mathrm{x})$ & Rmk \\
\hline 7. & $\begin{array}{l}\text { Appraising and promoting staff based on laid down } \\
\text { criteria. }\end{array}$ & 3.01 & VGE & 2.88 & GE & 2.59 & GE \\
\hline 8. & $\begin{array}{c}\text { Removing work alienation through counselling of staff } \\
\text { during and after appraisal. }\end{array}$ & 2.44 & ME & 2.32 & ME & 2.48 & LE \\
\hline 9. & $\begin{array}{l}\text { Appraising staff annually and promoting them as and } \\
\text { when due }\end{array}$ & 2.84 & GE & 2.61 & GE & 1.94 & LE \\
\hline 10. & $\begin{array}{l}\text { Forwarding appraisal reports of staff due for promotion } \\
\text { immediately to the appropriate quarters for utilization. }\end{array}$ & 2.64 & GE & 2.51 & GE & 1.84 & VLE \\
\hline 11. & $\begin{array}{l}\text { Identifying training and development needs of the staff } \\
\text { through appraisal. }\end{array}$ & 2.82 & GE & 2.77 & GE & 1.04 & VLE \\
\hline 12. & $\begin{array}{l}\text { Using appraisal to identify the strength and weaknesses of } \\
\text { staff for their development and better performance. }\end{array}$ & 2.55 & GE & 2.64 & GE & 1.07 & VLE \\
\hline & $\begin{array}{c}\text { Grand Mean } \\
\end{array}$ & 2.72 & GE & 2.62 & GE & 1.83 & VLE \\
\hline
\end{tabular}

Table 2: Mean Ratings on Staff Performance Appraisal and Promotion

Results in Table 2 revealed the universities and polytechnics conduct, to a great extent, performance appraisal and promotion objectively based on laid down procedures in the institution. The study also revealed that colleges of education in the area, to a very low extent, conduct performance appraisal and promotion objectively based on laid down procedures in the institution.

\section{DISCUSSION OF FINDINGS}

The finding of this study indicated that that universities, polytechnics and colleges of education in South Eastern Nigeria train and develop their staff to great and objectively based on laid down procedures in the institution. This finding is in agreement with Mullins (2010) who found that managers of higher institutions are always interested in the training and development of their 
staff. Similarly, Akpan (2019) found that higher institutions encourage their staff to take part in-service training programmes. Again Chiekezie, Nzewi and Orogbu (2009) found that vice chancellors did recommend their staff for in-service training programmes.

Another finding of the study indicated that the universities and polytechnics conduct, to a great extent, performance appraisal and promotion objectively based on laid down procedures in the institution. The study also revealed that colleges of education in the area, to a very low extent, conduct performance appraisal and promotion objectively based on laid down procedures in the institution.

This finding is in disagreement with Onah (2018) who found that appraisals and promotion in polytechnics are based on the discretion of the Rector. The reason for this difference could be that Onah studied private polytechnics. In the same vein, Biose (2003) found that Rectors and Provost of most private polytechnics colleges of education do not appraise their staff annually and as such, do not promote them accordingly.

\section{CONCLUSION}

Tertiary institutions in South Eastern Nigeria train and develop their staff to great and objectively based on laid down procedures in the institution. Unlike universities and polytechnics, colleges of education in the area, to a very low extent, conduct performance appraisal and promotion objectively based on laid down procedures in the institution.

\section{RECOMMENDATIONS}

Colleges of education in South Eastern Nigeria should conduct performance appraisal and promotion to a great extent and objectively based on laid down procedures in the institution.

Tertiary institutions in South Eastern Nigeria should continue to train and develop their staff to great and objectively based on laid down procedures in the institution.

\section{REFERENCES}

[1]. Ajayi, I.A and Omirin, F.F. (2007). The use of management information system. Benin City: Wisdom Publishers.

[2]. Akpan, C.P. (2018). Lecturers' perception of the role of ICT in the management of university education for sustainable development in Nigeria. Journal of Education Administration and Planning. Faculty of Education, Ebonyi State University, Abakaliki.

[3]. Armstrong, M. (2009). Armstrong's hand book of human resource management practice (1 $1^{\text {th }}$ ed.). London: Saxon.
[4]. Boxall, P.F., Purcel J. and Wright, P. (2007). The goals of HRM. P. Boxal, J. Purcell \& P. Wright (ed). Oxford handbooks of human resource management. Oxford: University Press.

[5]. Byars, L.L., \& Rue, L.W. (2004). Human resource management. New York: McGraw Hill.

[6]. Chiekezie, O.M. Nzewei, N.H. and Orogbu, O.L. (2009). Management: A practical approach. Awka: Mount Carmel.

[7]. Cole, G.A. (2002). Personnel and human resource management. London: TJ International.

[8]. Grinshaw, D. and Robbery, J. (2007). Economics and HRM, in (Eds) P. Boxall, J. Purcell \& P. Wright, Oxford handbook of human resource management. Oxford: Oxford University.

[9]. Guest, D.E. (1990). Human resource management and industrial relations. Journal of management and industrial relations, 14 (5), 503 -21.

[10]. Haslinda, A. (2009). Illuslararasi Sosyal, Arast irinaler Dergisi: The Journal of International Social research volume 2/9 fall 2009. en.Wikipedia.org/wiki/human resources. Retrieved Tuesday $14^{\text {th }}$ May, 2011.

[11]. Kelly, D. (2001). Dual perception of HRD. Issues for policy. http://eri.wikipedia.org/wikimanagment.retrieved Wed 8th July 2011.

[12]. Lucky, T. (2011). Management information system. California: Jossey Bass.

[13]. Mullins, L.J. (2010). Management and Organizational behavior $\left(9^{\text {th }} \mathrm{ed}\right)$. London: Pretence Hall.

[14]. Ndu, A. (2002). Staff personnel management in school. In H.G.N. Osuji \& A.Ndu (ed). Educational Administration for college of education and universities, 108 - 124- Owerri: Toney Ben.

[15]. Ndu, A.N., Ocho, L.O., \& Okeke, B.S. (1997). Dynamics of educational administration and management: The Nigerian perspective (ed). Awka: Meks.

[16]. Onah, F.O., (2018). Human resource management $\left(2^{\text {nd }}\right.$ ed). Enugu: John Jacob's Classic.

[17]. Sambo, A. (2011). Management information system and university administration. University System News: A Quarterly Publication of NUC. Special November Edition, 11, 12 -16.

[18]. Storey, J. (1995). Human resource management: A critical text London: Routledge. 